\title{
Deposition, Incubation Period and Hatching of Eggs from Triatoma juazeirensis Costa \& Felix and Triatoma sherlocki Papa, Jurberg, Carcavallo, Cerqueira \& Barata (Hemiptera: Reduviidae) under Laboratory Conditions
}

Vanessa Lima Neiva ${ }^{\bowtie}$, Marcia Gumiel, Marli Maria Lima, Teresa Cristina Monte Gonçalves, David William Provance, Carlos Eduardo Almeida \& Jane Costa

1. Fundação Oswaldo Cruz, e-mail: vanessaln@ioc.fiocruz.br (Autor para correspondência ${ }^{\bowtie}$ ), mgumiel@ioc.fiocruz.br, mmlima@ioc.fiocruz.br, tcmonte@ioc.fiocruz.br, billp@ioc.fiocruz.br, almeidace@ioc.fiocruz.br, jcosta@ioc.fiocruz.br.

\author{
EntomoBrasilis 5 (2): 130-136 (2012)
}

\begin{abstract}
Triatoma juazeirensis Costa \& Felix and Triatoma sherlocki Papa, Jurberg, Carcavallo, Cerqueira \& Barata are members of the Triatoma brasiliensis Neiva, 1911 species complex. Discovered in the state of Bahia, Brazil, collections from both natural and artificial habitats revealed that they can be found infected by Trypanosoma cruzi (Chagas) suggesting a potential to be vectors for Chagas disease. To contribute to the evaluation of this potential, the capacity of each species to proliferate under laboratory conditions was measured by the number of eggs laid, the rate of hatching and the incubation time over a 22-week period. Thirty pairs, fifteen of each species, were maintained under laboratory conditions by weekly feedings on mice, Mus musculus (Linnaeus). The comparisons of laid and hatched eggs of T.juazeirensis and T. sherlocki were analyzed by $t$-test and Mann-Whitney test. When $\mathrm{p}$ value of $<0.01$ it was considered statistically significant. For comparison of the average longevity, a chi-square analysis was used. When $\mathrm{p}>0.01$, the average longevity was not considered statistically different. The two species presented similar incubation periods for their eggs, but $T$. juazeirensis demonstrated greater reproductive potential than $T$. sherlocki. The females of $T$. sherlocki deposited significantly fewer eggs with a lower rate of viability. Results suggest that T. juazeirensis is a more serious threat, concerning to these reproductive features. Considering the longevity, no significant differences could be noticed.
\end{abstract}

Keywords: Reproduction; Triatominae; Triatoma brasiliensis complex.

Oviposição, Período de Incubação e Eclosão dos Ovos de Triatoma juazeirensis Costa \& Felix e Triatoma sherlocki Papa, Jurberg, Carcavallo, Cerqueira \& Barata (Hemiptera: Reduviidae) em Condições de Laboratório

Resumo. Triatoma juazeirensis Costa \& Felix e Triatoma sherlocki Papa, Jurberg, Carcavallo, Cerqueira \& Barata são membros do complexo de espécies Triatoma brasiliensis Neiva, 1911. Descobertas no estado da Bahia, Brasil, coletas em ambos os habitats natural e artificial revelaram que essas espécies são encontradas naturalmente infectadas por Trypanosoma cruzi (Chagas) sugerindo que ambos os vetores estão, provavelmente, associados à transmissão da doença de Chagas na região. Com o objetivo de contribuir para avaliação da capacidade vetorial das duas espécies, parâmetros biológicos como: fecundidade, fertilidade, período de incubação dos ovos e longevidade das fêmeas foram analisados comparativamente. Trinta casais individualizados, 15 de T. juazeirensis e 15 de T. sherlocki, foram alimentados em camundongos Mus musculus (Linnaeus) semanalmente e mantidos sob condições ambientais. Os ovos foram coletados e individualizados em frascos separados por data de postura até a eclosão das ninfas. A comparação das médias da oviposição e da eclosão de T. juazeirensis e T. sherlocki foi realizada pelo test T seguida do test de Mann-Whitney, quando $p<0,01$ a diferença foi considerada estatisticamente significativa. Para comparação das médias de longevidade aplicou-se o teste Qui-quadrado, quando p>0,o1 as médias de longevidade não foram consideradas estatisticamente diferentes. As duas espécies apresentaram períodos similares de incubação dos ovos, entretanto, T. juazeirensis demonstrou maior potencial reprodutivo, com fecundidade e fertilidade superiores a T. sherlocki, em condições de laboratório. Quanto à longevidade, as fêmeas de T. sherlocki e T. juazeirensis não apresentaram diferenças significativas.

Palavras-Chave: Complexo Triatoma brasiliensis; Reprodução; Triatominae.

A merican trypanosomiasis is one of the most widely distributed diseases in the Americas, caused by the parasite Trypanosoma cruzi (Chagas) (Kinetoplastida: Trypanosomatidae), the etiological agent (VInHAEs \& DiAS 2000). The underlying cause of the infection is the natural transmission of $T$. cruzi through members of a subfamily of blood-sucking insects, Triatominae (Hemiptera, Reduviidae). An estimated eight million people are currently infected and another 28 million people are at risk (WHо/CTD 2009). It is expanding into a global issue with its appearance on other continents through human activities (COURA \& VIÑAS 2010).

Actually 143 individual insect species were described, ranging from the southern United States to southern Argentina (PoINAR 2005; SCHOFIELD \& GALVÃo 2009; GURGEL-GonÇALVES et al. 2012) In Brazil, a great campaign to control the Triatoma infestans (Klug) the vector responsible for most of cases of $T$. cruzi infection in South America, caused the reduction of its populations and now 
other vectors are replacing it (Diotaiuti et al. 1995; Almeida et al. 2000; Silveira 2011). Currently, the Triatoma brasiliensis Neiva is considered one of the most important vector in semiarid northeastern region of Brazil (CosTA et al. 2003a).

Recently, multidisciplinary studies suggest that of $T$. brasiliensis represent a complex species compounded by four members: Triatoma brasiliensis brasiliensis Neiva, Triatoma brasiliensis macromelasoma Galvão, Triatoma melanica Neiva \& Lent, Triatoma juazeirensis Costa \& Felix. In these studies, were analyzed the following data concerning four populations: 1 morphological, demonstrating differences in the ornamentation on the exochorion of the eggs (Costa et al. 1997a), 2 - isoenzymatic, where the analysis of nine loci by multilocus enzyme eletroforesis showed significant genetic distances (Costa et al. 1997b), 3 - ecological, proving by ecological niche modeling that the staining patterns are stable and not influenced by the different environments in which the populations are distributed (COSTA et al. 2002 ) 4 - biological, detecting low reproductive compatibility in crossing experiments (Costa et al. 2003b), 5 - genetic, by analyzing the mtDNA fragments of Cyt B, it was possible to detect genetic differentiation (MonTEIro et al. 2004). Later, MENDONÇA et al. (2009) by carrying out the sequencing of the mtDNA fragments of Cyt B and 16S ribosomal RNA it was possible to place the Triatoma sherlocki Papa, Jurberg, Carcavallo, Cerqueira \& Barata in T. brasiliensis complex.

Wild triatomines are possibly in a process of adaptation to the domestic environments, such as T. sherlocki with index of domicile density (0.36) comparable to other species considered domiciliated (Almeida et al. 2009). In the domicile, nymphs and adults were found in fissures in the walls of houses (built of mud, rocks, wood) and under the bed. In this inspection, it was observed a high diversity of predators, especially spiders, such as Bothriurus asper Pocock which may be responsible for the low density of bugs found (AlmEida et al. 2009). T. sherlocki has only been collected from the wild ecotope in community of Gentio do Ouro, Bahia State, presenting considerable densities of colonies captured (o:31 researcher / hour - Encantado; 1:50 researcher / hour - Santo Inácio) with $10.9 \%$ of natural infection by T. cruzi (Almeida et al. 2009). In the natural environment, is found in rock formations ( $\sim 596 \mathrm{~m}$ above sea level) devoid of vegetation. In this ecotope, $T$. sherlocki develop colonies in the crevices between the rocks, being found under rocks fragments or on their surface when they come out to feed themselves at night (ALmeida et al. 2009). In their micro-habitat, this triatomine divides his shelter with rodents [Kerodon rupestris (Wied-Neuwied)] animals very common in this environment (CERQUEIRA 1982) (unpublished data).

T. juazeirensis displayed a wider distribution within the state of Bahia in the natural and artificial ecotopes (Costa et al. 1998, 2003a). The analysis of data collected of triatomines in domiciliary units, recorded by FUNASA in the period of 1993-1999 showed that $T$. juazeirensis colonizes primarily the peridomicile (colonization index $=36.9$ - dwellings; 44.9 peridomicile) (Costa et al. 2003a). In the peridomicile, these triatomines are found under rocks, in wood fences around stables or animals and bundles of dry wood, which they feed themselves on animals present in this environment as goats, dogs and birds (Costa et al. 1998). In the town of Curaçá, Bahia State, domestic specimens were discovered colonizing wood and not rocky (as in wild habitat) suggesting a behavioral plasticity towards habitats (CARBajal De la Fuente et al. 2008). In wilderness, T. juazeirensis is found in different sites of the rock formations such as crevices between rocks, under rocks and over the rocks. The examination of the food source of wild triatomines showed that they may feed on opossum, armadillo and rodents (CosTa et al. 1998). Triatoma sherlocki and T.juazeirensis are phylogenetically related species found in the same ecotope (rock piles), and occur around $44 \mathrm{~km}$ far apart from each other in the state of Bahia, Brazil (MENDONÇA et al. 2009; Almeida et al. 2011).
Thus, determination of different biological parameters for triatomines is important for the analysis of their capacity as vectors for $T$. cruzi infections. These parameters include the oviparity, fertility, longevity, feeding patterns and defecation patterns (Brasileiro 1984; Costa et al. 1986; Lima et al. 1987; DAFLON-TEIXEIRA et al. 2009). Considering that both species infest human dwellings in the state of Bahia, the evaluation of vectorial capacity is important for future planning of actions to control infestations and studying the epidemiology of Chagas disease. The present work describe a comparison of the egglaying potential, fertility rate, egg incubation period and female longevity for $T$. sherlocki and $T$. juazeirensis under laboratory conditions. Additionally, these data provide insights to their capacity to be vectors.

\section{MATERIAL AND METHODS}

Origin of triatomines. T. juazeirensis and $T$. sherlocki used in the experiments were from colonies maintained in the "Laboratório de Biodiversidade Entomológica" of " Instituto Oswaldo Cruz-FIOCRUZ", at a rate $27^{\circ} \mathrm{C}$ and $75.5 \%$ relative humidity. The founders of the insect colonies were collected at the following locations in the state of Bahia: a total of 22 specimens of T. sherlocki ( 5 females, 2 males and 15 nymphs) were collected in the municipality of Gentio do Ouro, at the localities of Encantado $\left(11^{\circ} 13^{\prime} 20^{\prime \prime} \mathrm{S}, 42^{\circ} 46^{\prime} 37^{\prime \prime} \mathrm{W}\right.$ ) and 53 specimens (7 females, 9 males and 37 nymphs) at the locality of Santo Inácio ( $11^{\circ} 06^{\prime} 46^{\prime \prime}$ $\mathrm{S}, 42^{\circ} 43^{\prime} \mathrm{o6}$ " W). A total of 10 specimens of T. juazeirensis (2 females, 1 male and 7 nymphs) were collected in the municipality of Itaguaçu, locality of Toca do Cosme, (11. oo' $43^{\prime \prime} \mathrm{S} 42^{\circ} 23$ ' $56^{\prime \prime} \mathrm{W}$ ) and 34 specimens (9 females, 18 males and 7 nymphs) originated Gameleira, in the municipality of Central (11 08 '09" $\left.\mathrm{S} 42^{\circ} 06^{\prime} 46^{\prime \prime} \mathrm{W}\right)$.

Preparation of triatomines pairs. Fifth-instar nymphs from the insect colony were randomly selected by sex and segregated into different plastic bottles (4X4X9 $\mathrm{cm})$. Feeding was performed every two weeks on mice Mus musculus (Linnaeus) until imaginal ecdysis (procedure approved by CEUA - "Comitê de Ética no Uso de Animais da Fundação Oswaldo Cruz", license L-0064/o8). After the emergence of adults, 15 pairs each of $T$. juazeirensis and $T$. sherlocki were transferred to plastic becker ( $3 \mathrm{~cm}$ diameter and $8 \mathrm{~cm}$ height).

Triatomines feeding, oviposition and hatched. The insects were fed on mice (M. musculus) weekly and maintained in identical conditions. The containers were observed once a week for the presence of eggs. The eggs were collected and separate by date and the incubation period was determinated from the date of collection until hatching. In addition, the observation period of oviposition and hatched was in total 22 weeks. The 22 weeks period of observation was correlated with a decrease in the observed fertility and fecundity of both species.

Overall, for each experimental insect pair, the following data were recorded weekly: the number of eggs laid, the number of hatched eggs (fertility), the incubation period (time to hatching of eggs) and longevity. The viable and not viable eggs were checked at least for 42 days, before discarding. The comparisons of laid and hatched eggs of $T$. juazeirensis and $T$. sherlocki were analyzed by $t$-test and Mann-Whitney test. When $\mathrm{p}$ value of $<0.01$ it was considered statistically significant. For comparison of the average longevity, a chi-square analysis was used. When $\mathrm{p}>0.01$, the average longevity was considered statistically not different.

\section{RESULTS}

The observation period started when the adults emerged from the imaginal ecdysis and continued for a period of 154 days (22 weeks), which correlated with decreasing of observed laid egg. Therefore, data concerning the reproductive potential of each species based on egg and offspring production were derived from this observation period. 
The combined number of eggs collected from all T. juazeirensis breeder pairs was 2.055, ranging from 2 to 29 eggs with an average of 93 eggs per female (Table 1).

From T. sherlocki breeder pairs, a total of 734 eggs, ranging from 1 to 20 eggs on each occasion, exhibiting an average of 33 per female. From the plot in Figure 1 of the eggs collected each week, three observations are most notable. First, T. juazeirensis was capable of laying eggs within the first week after emergence, but the first eggs from $T$. sherlocki were only observed in the third week. Second, the capacity to lay eggs continued to increase over the next 5 weeks for $T$. juazeirensis and 7 weeks for $T$. sherlocki. Following this increase, the laying of eggs oscillated in number during the next 12 weeks (weeks 6-19) before a notable decreasing in the egg laying by week 20 The greatest average number of eggs laid by T.juazeirensis females was 12.5 in the 8th and 11th week. This was more than twice the greatest rate observed for T. sherlocki of 5.8 in the 12th week (Figure 1). The difference in egg-laying behavior between the two species was statistically different by the $t$-test $(t=4.6, p<0.01)$ and a non-parametric test, the Mann Whitney Test ( $\mathrm{p}<0.01)$.

All fifteen females of $T$. juazeirensis were observed to lay eggs and fourteen produced eggs that hatched. In comparison, thirteen females of $T$. sherlocki laid eggs and only nine produced offspring. From the eggs laid by the fourteen $T$. juazeirensis that produced offspring, 93.7\% hatched (Table 1). Of the eggs from the nine $T$. sherlocki, that produced offspring, $60.9 \%$ were recorded to hatch. The pattern of egg hatching closely matched the pattern observed for egg laying (Figures 1 and 2) for both species. According to the statistical tests applied, the number of hatched eggs is significantly higher in T. juazeirensis that of $T$. sherlocki $(\mathrm{t}=5.5 \mathrm{p}<0.01)$ and Mann Whitney $(\mathrm{p}<0.01)$.

The incubation time of eggs of T. juazeirensis and T. sherlocki ranged from 14 to 28 days (mean 20.2 days), the eggs were observed at least 42 days before discarding. Most eggs considered nonviable presented with a clear color and were twisted, not with a pink tint or the eye spots characteristic of fertile eggs. Some eggs were dark brown, but were completely dry. The ratio of viable to non-viable eggs varied over the observation period. $T$. juazeirensis females had a small peak of non-viable eggs early in weeks 2 and 3, but consistently laid primarily non-viable eggs until weeks 12 and 13 (Figure 3). This was in contrast to $T$. sherlocki females, which consistently laid more non-viable eggs (Figure 4).

Throughout the study, 80\% (12) of the T.juazeirensis females and 46.6\% (7) of the T. sherlocki females died. The average survival period was 113.7 days $(16.24$ weeks) $(\min =62, \max =154)$ for T. juazeirensis and $114.8(16.40$ weeks $)(\min =90, \max =154)$ for $T$. sherlocki (Table 2). While the number of deaths recorded for $T$. juazeirensis females was greater, the pattern of survival closely matched that of $T$. sherlocki females. The Chi-square test revealed that the averages were not statistically different $\left(\chi^{2}: 3.11\right.$, $\mathrm{p}>0.01)$.

Table 1. Egg-laying performed and hatching from eggs laid by 15 pairs Triatoma juazeirensis (Tj) and 15 pairs Triatoma sherlocki (Ts) over the period of 22 weeks.

\begin{tabular}{|c|c|c|c|c|c|c|}
\hline \multicolumn{4}{|c|}{ Eggs Collected } & \multicolumn{2}{|c|}{ Range } & \\
\hline & Total & Average & Std Dev & Min & $\operatorname{Max}$ & \\
\hline $\mathbf{T j}$ & 2055 & 93.5 & $55 \cdot 7$ & 2 & 29 & \\
\hline Ts & 734 & $33 \cdot 3$ & 24.8 & 1 & 20 & \\
\hline \multicolumn{4}{|c|}{ Hatched } & \multicolumn{2}{|c|}{ Range } & \% Hatched \\
\hline & Total & Average & Std Dev & Min & $\operatorname{Max}$ & \\
\hline $\mathbf{T j}$ & 1927 & 87.5 & \pm 55.2 & $\mathrm{O}$ & 28 & $93 \cdot 7$ \\
\hline Ts & 447 & 20.3 & \pm 15.8 & o & 20 & 60.9 \\
\hline
\end{tabular}

The difference in egg-laying behavior between the two species was statistically different by the $\mathrm{t}$-test $(\mathrm{t}=4.6, \mathrm{p}<0.01)$ and a non-parametric test, the Mann Whitney Test $(\mathrm{p}<0.01)$. According to the statistical tests applied, the number of hatched eggs is significantly higher in $T$. juazeirensis that of $T$. sherlocki $(\mathrm{t}=5.5 \mathrm{p}<0.01)$ and Mann Whitney $(\mathrm{p}<0.01)$.

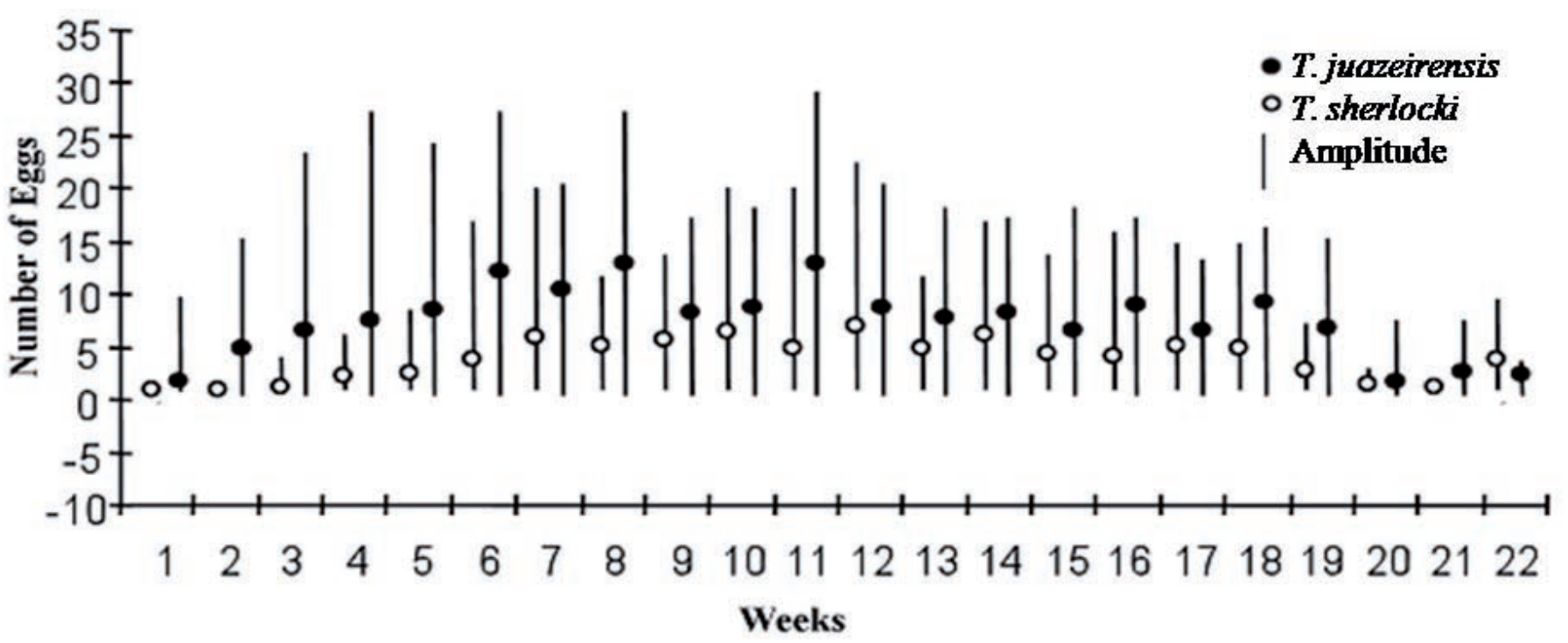

Figure 1. Average weekly deposition of eggs per female of Triatoma juazeirensis and Triatoma sherlocki over 22 weeks. 


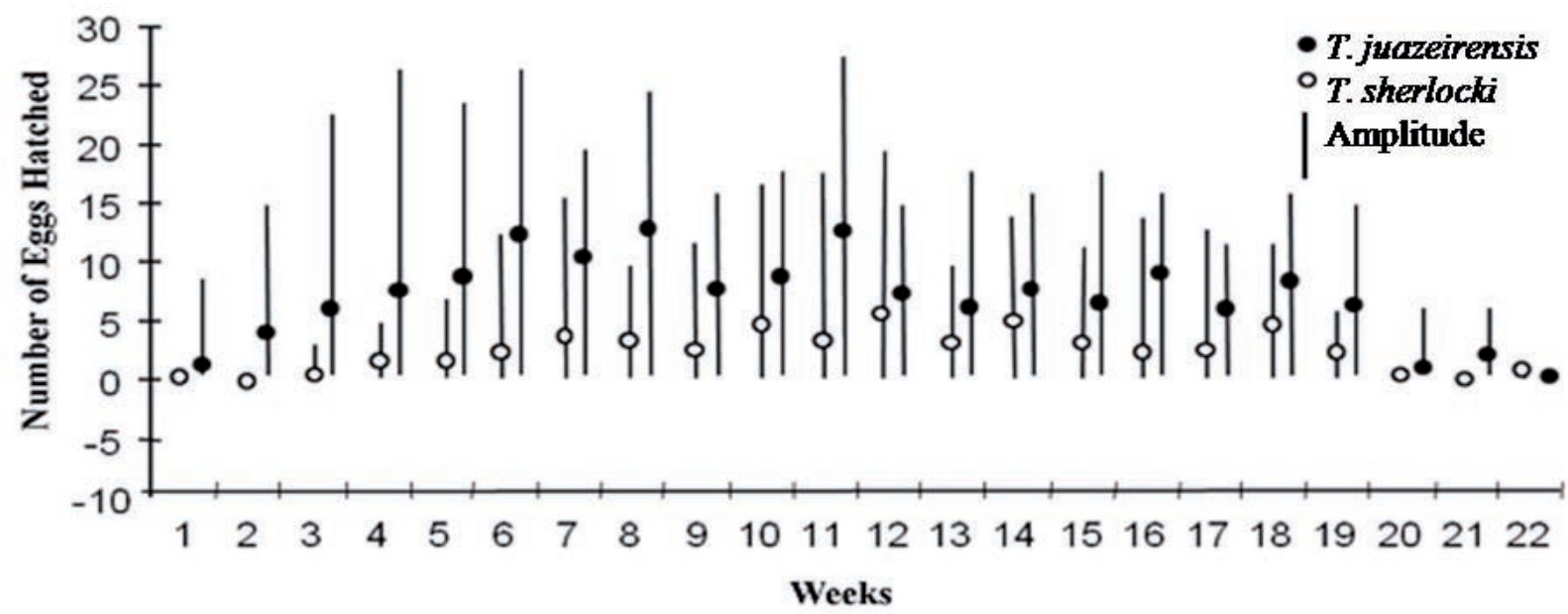

Figure 2. Weekly average of eggs hatched per female of Triatoma juazeirensis and Triatoma sherlocki from the 22 weeks period.

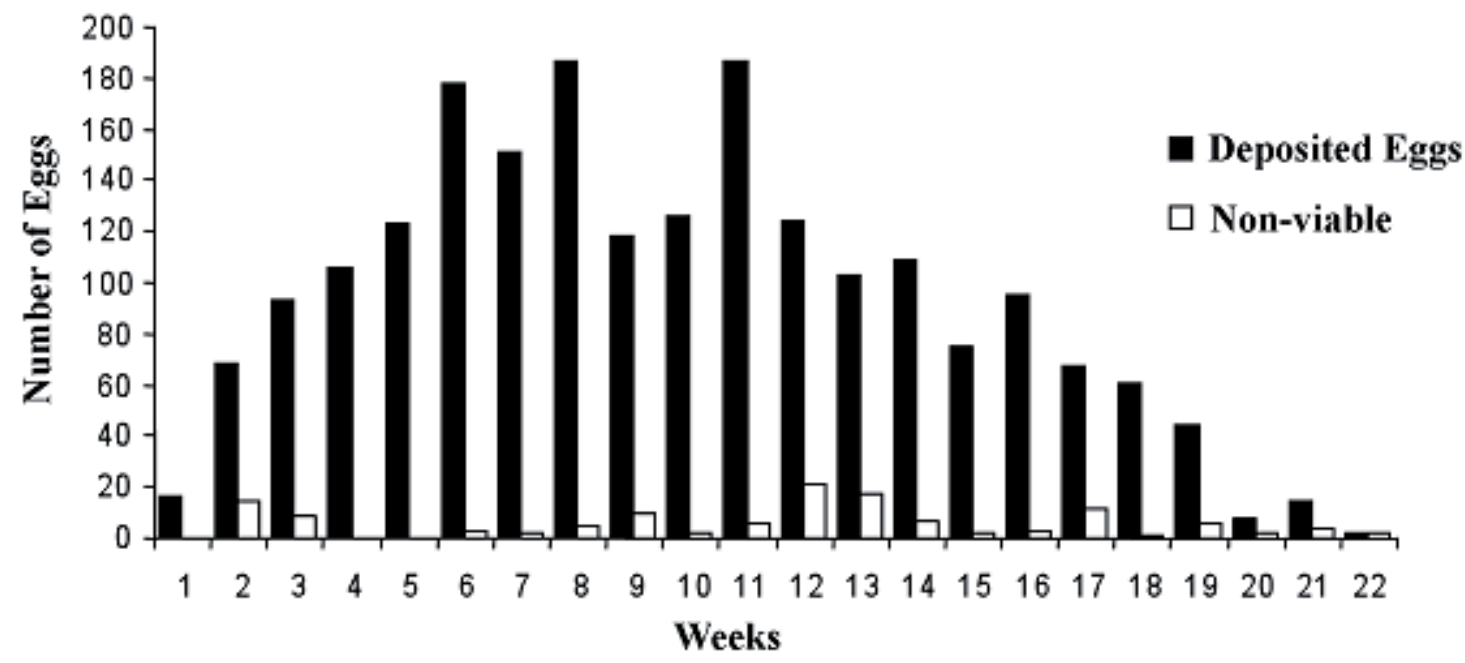

Figure 3. Viability of eggs deposited by Triatoma juazeirensis during the period of 22 weeks.

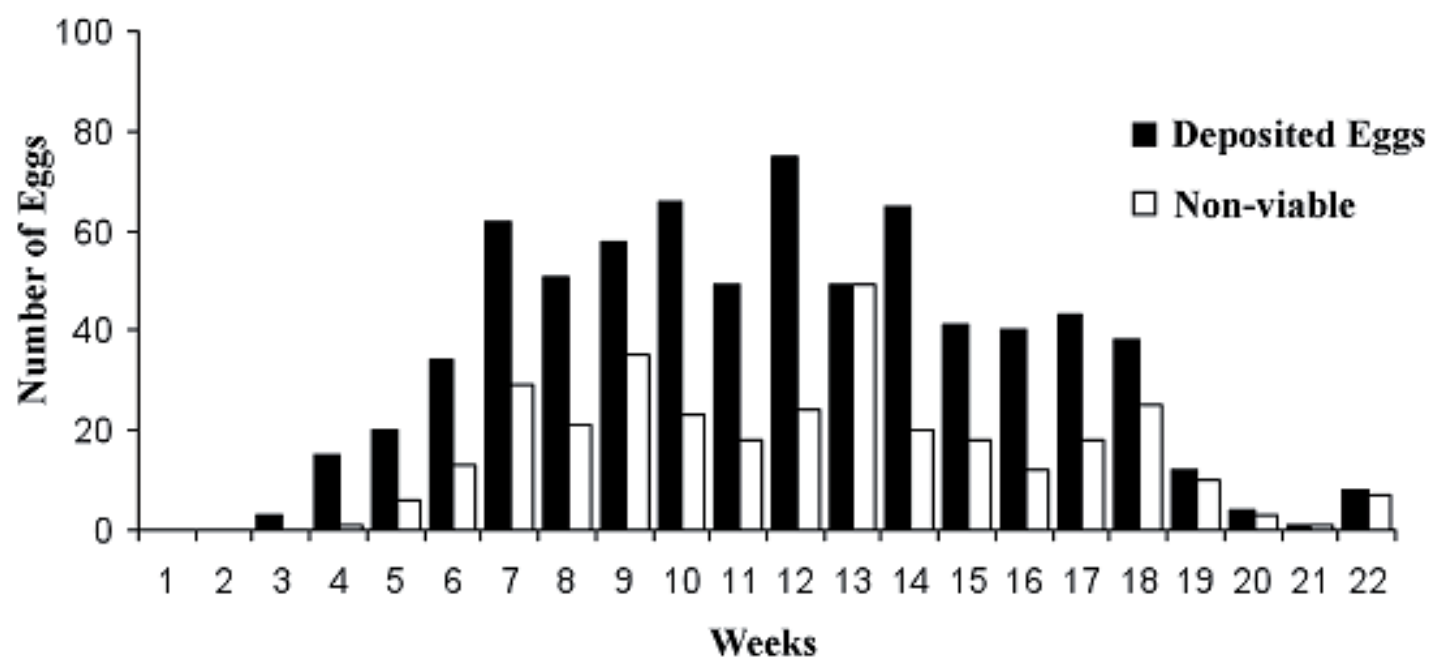

Figure 4. Viability of eggs deposited by Triatoma sherlocki during the period of 22 weeks.

Table 2. Longevity of females of Triatoma juazeirensis and Triatoma sherlocki, in days, from the 22 week period.

\begin{tabular}{cccccc|}
\hline Species & Total Deceased & Average & Std Dev & Earliest & Latest \\
\hline T.juazeirensis & 12 & 113.7 & \pm 24.4 & 62 & 154 \\
T. sherlocki & 7 & 114.8 & \pm 24.9 & 90 & 154 \\
\hline
\end{tabular}

Statistical Chi-square test $\left(\chi_{2}: 3.11, \mathrm{p}>0.01\right)$ the average longevity was not considered statistically different. 


\section{DISCUSSION}

In Brazil, campaign to control the $T$. infestans caused the reduction of its populations and now other vectors are replacing it (Diotaiuti et al. 1995; Almeida et al. 2000; Silveira 2011). On the other hand, the general trend of vectors of Chagas disease to adapt to human dwellings and peridomiciliary structures is not necessarily associated with the colonization of a previous domestic specie. According Ramsey \& Schofield (2003) the triatomines colonize houses seeking stable climates and access to food sources. Microtriatoma trinidadensis (Lent) and Belminus herreri Lent \& Wygodzinsky were found in houses in Bolivia and Colombia, respectively, which had not previously been colonized by domestic triatomines (DE LA Riva et al. de 2001; SANDOVAL et al. 2004). Studies by SANDOval et al. 2004 showed that B. herreri is attracted to the home in seek of food, where is found abundant invertebrate hosts in the form of cockroaches that would facilitate their population development.

Biological parameters of the triatomines such as: development of the biological cycle, egg laying rate, egg hatching rate, period of embryonic development among others, vary according to species and environmental conditions, and are greatly influenced by the availability of blood supply (BRASILEIRO 1984; SCHOFIELD 1985; Lima et al. 1987; DAFLON-TEIXEIRA et al. 2009). While biological data are available for many species, comparisons among studies are difficult due to differences in experimental design, especially in relation to temperature and humidity (often uncontrolled), feeding frequency, blood meal sources (ZÁrATE 1983), and methods of statistical analysis to interpret the results. Controlled experimental conditions when coincide with optimal conditions for a species may favor the high rate of reproduction (MARTínezIBARRA \& KatTHAin-Duchateau 1999). Although the present study was not conducted under controlled conditions, the use of laboratory conditions, ambient temperature and humidity and food, provides an estimate of the reproductive capacity of triatomines. Extrapolation from the laboratory data for natural populations are relatively easy in triatomines, since in the wild all stages of life occur in a single kind of environment and exhibit similar biological requirements (ZÁrATE 1983).

In Southern Cone countries, control of the primary insect vector, $T$. infestans, has been an effective measure against the incidence of Chagas disease. To maintain vigilance, it is necessary to focus on secondary vectors, including T. juazeirensis and T. sherlocki. Evaluation of their potential as vectors includes numerous biological parameters, especially the capacity to reproduce (BRASILEIRO 1984; Costa et al. 1986; Lima et al. 1987; Marassá et al. 1998; DAFLon-TeIXeIra et al. 2009). In this study, the data clearly demonstrate that $T$. juazeirensis has a greater reproductive capacity to propagate than $T$. sherlocki.

Compared with the data in the literature, T. juazeirensis was also more prolific in relation to $T$. brasiliensis (93.5 versus 53.4 respectively) that was maintained using pigeons (Columba livia Gmelin, 1789). (DAFLON-TEIXEIRA et al. 2009), but lower than T. brasiliensis (142) (SoAREs et al. 2000) and Triatoma rubrofasciata (De Geer) (242.9) (BRAGA et al. 1998), fed on mice (M. musculus). The difference in egg laying by T. brasiliensis displayed a difference based on the food source highlighting the influence exerted by feeding on the fertility and fecundity (COSTA et al. 1986, GUARNERI et al. 2000).

The egg hatching rate for T. juazeirensis and T. sherlocki were 93.7 and $60.9 \%$, respectively, whereas for $T$. brasiliensis by SOAREs et al. (2000), this rate was 92.5\% when maintained on mice, also under laboratory conditions. It must be stressed that $T$. brasiliensis is a phylogenetically related species to the ones herein analyzed. Two other species maintained on chickens [Gallus gallus (Linnaeus)], Triatoma sordida (Stål) and T. infestans, were recorded with rates of $91 \%$ and $94 \%$, respectively (Oscherov et al. 2004). However, other studies showed that the rates of egg hatching are variable for different species of triatomines (COSTA et al. 1986, MARASSÁ et al. 1998).

The number of copulations between the breeder pairs also contributes to the number of eggs deposited. Several studies have demonstrated that mating is a stimulus for the production of eggs, making females more fecund (BRASILEIRO 1984; LiMA et al. 1987; DAFLON-TEIXEIRA et al. 2009). The eggs laid by T.juazeirensis also showed the highest percentage (93.7\%) of hatching compared to $T$. sherlocki (60.9\%). These data show that the first species had a higher reproductive success in the laboratory conditions used here. This suggests that the group of males and females of T. juazeirensis were fertile.

The developmental period for the eggs of T. juazeirensis and $T$. sherlocki showed similar lengths with an average of 20.2 days and ranging from 14 to 28 days at temperatures that ranged between $21.6{ }^{\circ} \mathrm{C}$ to $30{ }^{\circ} \mathrm{C}$. The comparison between these periods has not been significant. The incubation period of eggs from $T$. brasiliensis was reported to be 25 days at $24 \pm 2{ }^{\circ} \mathrm{C}$ (SOAREs et al. 2000), while Triatoma pseudomaculata Corrêa \& Espínola, 1964 was 18 days at $28^{\circ} \mathrm{C}$ (GonçALVEs et al. 1997). The embryonic development of eggs of several species of triatomines is also influenced by temperature, as first demonstrated by NEIVA (1913) for T. infestans. RANGEL (1982) evaluated the effects of that variable in the period of incubation of the eggs of other 13 species, noting that for eggs incubated between $30{ }^{\circ} \mathrm{C}$ and 34 ${ }^{\circ} \mathrm{C}$, the incubation period was shorter than in the control group maintained at $25{ }^{\circ} \mathrm{C} \pm 3{ }^{\circ} \mathrm{C}$.

The survival rate of T.juazeirensis and T. sherlocki was recorded only for females that died during the experiment. Thus, we observed median survival of 16.24 weeks and 16.4 weeks, respectively. Although the averages for these two species are comparable, it is important to note that until the last day of observation (154 days) of 15 females of $T$. juazeirensis 12 died while in the same period, only seven females of $T$. sherlocki died (Table 3). However, in applying the statistical PARA test Chisquare ( $x 2: 3.11, p>0.01)$ revealed that the averages were not statistically different. Our results are consistent with the median survival reported for $T$. infestans (16.40 weeks) (RABINOvicH 1972).

The species Rhodnius prolixus Stål, Triatoma rubrovaria (Blanchard), T. rubrofasciata as and 18 other species of triatomines all demonstrate hatching rates that are dependent on the ambient conditions including temperature and humidity (Gomez-Núnez 1964; Braga et al. 1998; Damborsky et al. 2005). Together, these observations suggest that the use of laboratory conditions provide distinct rates obtained for egg laying and hatching reflect the variable capacity of a particular species to be adapted to lab conditions. Therefore, since $T$. juazeirensis exhibited greater reproductive fitness for all variables analyzed, we suggest that this species might be better adapted than $T$. sherlocki to the lab conditions of which they were submitted.

The differences between $T$. juazeirensis and $T$. sherlocki on oviparity and fertility were statistically significant and informative, suggesting that the biotic potential between the two species is distinct. These features observed for T. juazeirensis could give it an advantage over T. sherlocki. Maybe these features are involved in the low domiciliary infestation rates observed for T. sherlocki (AlmEIDA et al. 2009). Although not yet found in sympatry, they inhabit biotopes with similar characteristics. Other aspects bionomic as feeding time, amount of blood ingested, time of defecation and starvation resistance are likely to complement these results, contributing to the understanding of the importance of these species as a potential vector of the parasite T. cruzi.

In view of the results obtained here and other previously published data on T.juazeirensis and T. sherlocki, it is recommended that a 
constant surveillance should be maintained as part of an effective control program for these species; particularly in small isolated communities such as Santo Inácio and Encantado, Bahia State. In these small communities, the mining activities performed by miners favor the building of homes in undeveloped areas that promotes contact with potential vectors of $T$. cruzi. Furthermore, the behavior of $T$. juazeirensis to colonize also wood habitats increases its possible colonization of peridomestic spaces (CARbajal De la Fuente et al. 2008).

Behavioral plasticity appears to be associated with the ability of triatomines to colonize and re-colonize domiciles after insecticide spraying, as well as different ecotopes (NoIREAU et al. 2009). In addition to the opportunity of home environments to provide stable climates and access to food sources (RAMSEY \& SCHOFIELD 2003) contribute for establishing numerous colonies. Together, they positively influence the capacity of triatomines to re-infest the domestic environment after the application of insecticides. High population densities of triatomines in human dwellings has been associated to the Chagas disease transmission (DiAs 1995), which is surely related to the reproductive potential of a given species.

\section{ACKNOWLEDGEMENTS AND FUNDING}

This research was supported by the Brazilian National Council for Scientific and Technological Development (CNPq) and The State of São Paulo Research Foundation (FAPESP).

\section{REFERENCES}

Almeida, C.E., E. Folly-Ramos, A.T. Peterson, V. Lima-Neiva, M. Gumiel, R. Duarte, M.M. Lima, M. Locks, M. Beltrão \& J. Costa, 2009. Could Triatoma sherlocki be vectoring Chagas disease in small mining communities in Bahia, Brazil? Medical and Veterinary Entomology, 23: 410-417.

Almeida, C.E., H.L. Oliveira, N. Correia, L.L. Dornak, M. Gumiel, V.L. Neiva, M. Harry, V.J. Mendonça, J. Costa \& C. Galvão, 2011. Dispersion capacity of T. sherlocki, T. juazeirensis and laboratory-bred hybrids. Acta Tropica, 122: 71-79.

Almeida, C.E., M.C. Vinhaes, J.R. Almeida, A.C. Silveira \& J. Costa, 2000. Monitoring the domiciliary and peridomiciliary invasion process of Triatoma rubrovaria in the state of Rio Grande do Sul, Brazil. Memórias do Instituto Oswaldo Cruz, 95: 761-768.

Braga, M.V., Z.T. Pinto \& M.M. Lima, 1998. Life Cycle and Reproductive Patterns of Triatoma rubrofasciata (De Geer, 1773) (Hemiptera: Reduviidae), under Laboratory Conditions. Memórias do Instituto Oswaldo Cruz, 93: 539-542.

Brasileiro, V.L.F., 1984. Fecundidade e fertilidade da fêmea de Triatoma brasiliensis (Hemiptera: Reduviidae). I. Influência da cópula e da nutrição. Revista Brasileira de Entomologia, 28: 441-449.

Carbajal De la Fuente, A.L., A. Dias-Lima, C.M. Lopes, L. Emperaire, A. Walter, A. Ferreira, I. Sherlock \& F. Noireau, 2008. Behavioral Plasticity of Triatominae Related to Habitat Selection in Northeast Brazil. Journal of Medical Entomology, 45: 14-19.

Costa, J., C.E. Almeida, E.M. Dotson, A. Lins, M. Vinhaes, A.C. Silveira \& C.B. Beard, 2003a. The epidemiologic importance of Triatoma brasiliensis as a Chagas disease vector in Brazil: a revision of domiciliary captures during 1993-1999. Memórias do Instituto Oswaldo Cruz, 98: 443-449.

Costa, J., C.E. Almeida, J.P. Dujardin \& C.B. Beard, 2003b. Crossing experiments detect genetic incompatibility among populations of Triatoma brasiliensis Neiva, 1911(Heteroptera, Reduviidae, Triatominae). Memórias do Instituto Oswaldo Cruz, 98: 637-639.

Costa, J., O.M. Barth, V. Marchon-Silva, C.E. Almeida, M.G. Freitas-Sibajev \& F. Panzera, 1997a. Morphological studies on the Triatoma brasiliensis Neiva, 1911 (Hemiptera,
Reduviidae, Triatominae) - Genital structures and eggs of different chromatic forms. Memórias do Instituto Oswaldo Cruz, 92: 493-498.

Costa, J., M.G. Freitas-Sibajev, V. Marchon-Silva, M.Q. Pires \& R. Pacheco, 1997b. Isoenzymes detect variation in populations of Triatoma brasiliensis (Hemiptera-Reduviidae-Triatominae). Memórias do Instituto Oswaldo Cruz, 92: 459-464.

Costa, J., J.R. Almeida, C. Britto, R. Duarte, V. Marchon-Silva \& R. Pacheco, 1998. Ecotopes, natural infection and trophic resources of Triatoma brasiliensis (Hemiptera, Reduviidae, Triatominae). Memórias do Instituto Oswaldo Cruz, 93: 7-13.

Costa, J.M., J. Jurberg \& J.R. Almeida, 1986. Estudos bionômicos de Dipetalogaster maximus (Uhler,1894) (HemipteraTriatominae). I- Influência da dieta sobre o ritmo de postura, viabilidade dos ovos, curva de fertilidade e mortalidade das fêmeas. Memórias do Instituto Oswaldo Cruz, 81: 365-380.

Costa, J., P. Townsend \& C.B. Beard, 2002. Ecological niche modeling and differentiation of populations of Triatoma brasiliensis Neiva, 1911, the most important Chagas disease vector in Northeastern Brazil. American Journal of Tropical Medicine \& Hygiene, 67: 516-520.

Coura, J.R. \& P.A. Viñas, 2010. Chagas disease: a new worldwide challenge. Nature 465: S6-S7.

Daflon-Teixeira, N.F., A.F. Carvalho-Costa, R.G. Chiang \& M.M. Lima, 2009. Influence of blood meal and mating in reproduction patterns of Triatoma brasiliensis females (Hemiptera: Reduviidae) under laboratory conditions. Memórias do Instituto Oswaldo Cruz, 104: 1031-1034.

Damborsky, M.P., M.E. Bar \& D. Gorla, 2005. Life cycle and reproductive patterns of Triatoma rubrovaria (Blanchard, 1843) (Hemiptera: Reduviidae) under constant and fluctuating conditions of temperature and humidity. Revista da Sociedade Brasileira de Medicina Tropical, 38: 433-437.

De La Riva, J., A. Matias, M. Torrez, E. Martínez \& J.P. Dujardin, 2001. Adult and nymphs of Microtriatoma trinidadensis (Lent, 1951) (Hemiptera: Reduviidae) caught from peridomestic environment in Bolivia. Memórias do Instituto Oswaldo Cruz, 96: 889-894.

Dias, J.C.P., 1995. Prioridades de pesquisa no controle da doença de Chagas. Revista da Sociedade Brasileira de Medicina Tropical, 28: 23-26.

Diotaiuti, L., O.R. Paula, P.L. Falcão \& J.C.P. Dias, 1995. Avaliação do programa de controle vetorial da doença de Chagas em Minas Gerais, Brasil, com referência especial ao Triatoma sordida. Boletín de la Oficina Sanitaria Panamericana, 118: 211-219.

Gomez-Núnez, J.C., 1964. Mass rearing of Rhodnius prolixus. Bull World Health Organ, 31: 56-57.

Gonçalves, T.C.M., V. Cunha, E. Oliveira \& J. Jurberg, 1997. Alguns aspectos da biologia de Triatoma pseudomaculata Corrêa \& Espínola, 1964, em condições de laboratório. Memórias do Instituto Oswaldo Cruz, 92: 275-280.

Guarneri, A. A., M.H. Pereira \& L. Diotaiuti, 2000. Influence of the blood meal source on the development of Triatoma infestans, Triatoma brasiliensis, Triatoma sordida and Triatoma pseudomaculata (Heteroptera: Reduviidae). Journal of Medical Entomology, 37: 373-379.

Gurgel-Gonçalves, R., C. Galvão, J. Costa \& A. Townsend Peterson., 2012. Geographic Distribution of Chagas Disease Vectors in Brazil Based on Ecological Niche Modeling. Journal of Tropical Medicine, 2012: 1-15.

Lima, M.M., P. Jurberg \& J.R. Almeida, 1987. Behavior of triatomines (Hemiptera: Reduviidae) vectors of Chagas disease. IV. Fecundity, fertility and longevity of Panstrongylus megistus (Burm, 1835) pairs and virgin females starved under laboratory conditions. Memórias do Instituto Oswaldo Cruz, 82: 501-509.

Marassá, A.M., R.M.O. Veiga-Barreiros, R.H.P. Moraes, R.M.G. Andrade, A. Castillo \& F.M.A. Corrêa, 1998. Observações 
sobre oviposição, eclosão e tempo de vida de Triatoma matogrossensis Leite \& Barbosa, 1953 (HemipteraReduviidae) em função da alimentação em pombos e coelhos. Revista da Sociedade Brasileira de Medicina Tropical, 31: 361-365.

Martínez-Ibarra J.A. \& G. Katthain-Duchateau, 1999. Biology of Triatoma pallidipennis Stal 1945 (Hemiptera: Reduviidae:Triatominae) under Laboratory Conditions. Memórias do Instituto Oswaldo Cruz, 94: 837-839.

Mendonça, V.J., M.T.A. Silva, J. Martins, M. Bacci Júnior, J. Costa, R.M.B. Cicarelli \& J.A. Rosa, 2009. Phylogeny of Triatoma sherlocki (Hemiptera: Reduviidae: Triatominae) inferred from two mitochondrial genes suggests its location within the Triatoma brasiliensis complex. American Journal of Tropical Medicine and Hygiene, 81: 858-854.

Monteiro, F.A., M.J. Donnelly, C.B. Beard \& J. Costa, 2004 Nested clade and phylogeographic analyses of the Chagas disease vector Triatoma brasiliensis in Northeast Brazil. Molecular Phylogenetic Evololution, 32: 46-56.

Neiva, A., 1913. Informações sobre a biologia da vinhuca, Triatoma infestans. Memórias do Instituto Oswaldo Cruz, 5: 24-31.

Noireau, F., P. Diosque \& A.M. Jansen, 2009. Trypanosoma cruzi: adaptation to its vectors and its hosts. Veterinary Research, 40: 1-26.

Oscherov, E.B., M.P. Damborsky, M.E. Bar \& D.E. Gorla, 2004. Competition between vectors of Chagas disease, Triatoma infestans and T. sordida: effects on fecundity and mortality. Medical and Veterinary Entomology, 18: 323-328.

Poinar, G.J., 2005. Triatoma dominicana sp. n. (Hemiptera: Reduviidae: Triatominae), and Trypanosoma antiquus sp. n. (Stercoraria: Trypanosomatidae), the First Fossil Evidence of a Triatomine-Trypanosomatid Vector Association. VectorBorne and Zoonotic disease 5: 72-81.

Rabinovich, J.E., 1972. Vital statistics of Triatominae (Hemiptera - Reduviidae) under laboratory conditions. I- Triatoma infestans (Klug, 1834). Journal of Medical Entomology, 9: 351-370.

Ramsey, J.M. \& C.J. Schofield, 2003. Control of Chagas disease vectors. Salud Pública de México 45: 123-128.

Rangel, E.F., 1982. Observações sobre a influência da temperatura no período de incubação dos ovos de Triatominae (Hemiptera - Reduviidae). Anais da Sociedade Entomológica do Brasil, 11: 255-299.

Sandoval C.M., R. Duarte, R. Gutíerrez, D.S. Rocha, V.M. Angulo, L. Esteban, M. Reyes, J. Jurberg \& C. Galvão, 2004. Feeding sources and natural infection of Belminus herreri (Hemiptera, Reduviidae, Triatominae) from dwellings in Cesar, Colombia. Memórias do Instituto Oswaldo Cruz, 99: 137-140.

Schofield, C.J., 1985. Population dynamics and control of Triatoma infestans. Annales de la Societé Belge de Medecine, 65: 149-164.

Schofield, C.J. \& C. Galvão, 2009. Classification, evolution and species groups within the Triatominae. Acta Tropica, 110: 88100.

Silveira, A. C., 2011 Os novos desafios e perspectivas futuras do controle. Revista da Sociedade Brasileira de Medicina tropical, 44: 122-124.

Soares, R.P., L. Graças-Evangelista, L.S. Laranja \& L. Diataiuti, 2000. Population dynamics and feeding behavior of Triatoma brasiliensis and Triatoma pseudomaculata, main vectors of Chagas disease in Northeastern Brazil. Memórias do Instituto Oswaldo Cruz, 95: 151-155.

Vinhaes, M.C. \& J.C.P. Dias, 2000. Doença de Chagas no Brasil. Caderno de Saúde Pública, 16: 7-12.

WHO/CTD, 2009. Chagas disease (American trypanosomiasis). Disponível em <http://www.who.int/neglected diseases/ diseases/chagas/en/index.html $>$ [Acesso em Janeiro de 2012].

Zárate, L.G., 1983. The biology and behavior of Triatoma barberi (Hemiptera: Reduvidae) in Mexico. III. Completion of the life cycle adult longevity, and egg production under optimal feeding conditions. Journal of Medical Entomology, 20: 485497 .

Recebido em: 14/12/2011

Aceito em: 25/o3/2012

Como citar este artigo:

Neiva, V.L., M. Gumiel, M.M. Lima, T.C.M. Gonçalves, D.W. Provance, C.E. Almeida \& J. Costa, 2012. Deposition, Incubation Period and Hatching of Eggs from Triatoma juazeirensis Costa \& Felix and Triatoma sherlocki Papa, Jurberg, Carcavallo, Cerqueira \& Barata (Hemiptera: Reduviidae) under Laboratory Conditions. EntomoBrasilis, 5(1): 130-136.

Acessível em: http://www.periodico.ebras.bio.br/ojs/index.php/ebras/article/view/215
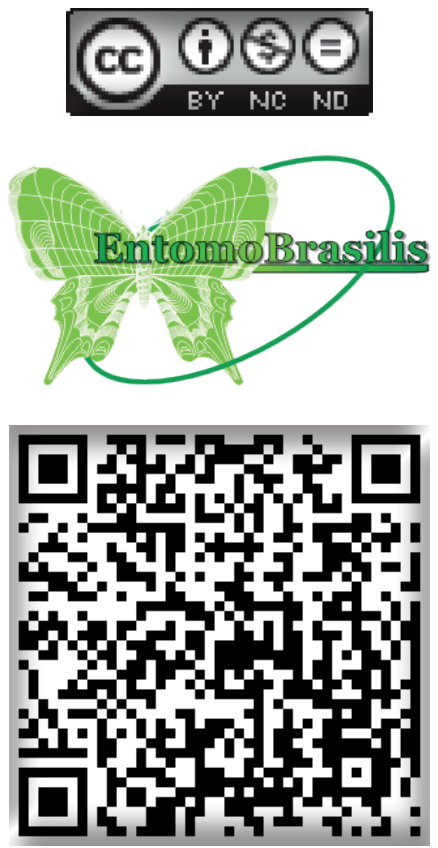